\title{
Could resource rents finance universal access to infrastructure? A first exploration of needs and rents
}

SABINE FUSS

Mercator Research Institute on Global Commons and Climate Change, Torgauer Strasse 12-15, 10829 Berlin, Germany.

Email:fuss@mcc-berlin.net

\section{CLAUDINE CHEN}

Mercator Research Institute on Global Commons and Climate Change, Germany

\author{
MICHAEL JAKOB
}

Mercator Research Institute on Global Commons and Climate Change; Potsdam Institute for Climate Change Impact Research, Germany

ANNIKA MARXEN

Mercator Research Institute on Global Commons and Climate Change; Technical University Berlin, Germany

NARASIMHA D. RAO

International Institute for Applied Systems Analysis, Austria

OTTMAR EDENHOFER

Mercator Research Institute on Global Commons and Climate Change; Technische Universität Berlin; Potsdam Institute for Climate Change Impact Research, Germany

Submitted 18 September 2015; accepted 7 April 2016; first published online 24 June 2016

ABSTRACT. It is often argued that, ethically, resource rents should accrue to all citizens. Yet, in reality, the rents from exploiting national resources are often concentrated in the

The authors have benefitted from discussions with Paul Segal, and are thankful for feedback from Jan Steckel, David Kapfer and other colleagues at MCC. They acknowledge advice on the cost of electricity access by Shonali Pachauri of IIASA, and on the cost of providing water and sanitation by Guy Hutton of the World Bank. Finally, they thank Santiago Tascon for research assistance. 
hands of a few. If resource rents were to be taxed, on the other hand, substantial amounts of public money could be raised and used to cover the population's infrastructure needs, such as access to electricity, water, sanitation, communication technology and roads, which all play important roles in a nation's economic development process. Here, the authors examine to what extent existing resource rents could be used to provide universal access to these infrastructures.

\section{Introduction}

Access to basic infrastructure services - including water, sanitation, electricity, transport and telecommunications - is a fundamental underpinning of human development, understood as creating the capabilities for individuals to achieve their personal objectives (Drèze and Sen, 2013). Even though investments in the respective infrastructures are likely to yield large returns (Calderon and Serven, 2014), in the absence of stable institutions and without access to capital markets it is unlikely that these public goods will be provided at the socially desirable level (Estache and Fay, 2007). As a result, infrastructure access gaps - especially within the developing world - are still high (see section 3.1 for details).

In this study, we argue that resource rent taxation constitutes a promising option to finance basic infrastructure, at least as part of the required investments to close these gaps, on two accounts. First, taxes on fixed factors, such as natural resources, constitute an efficient, distortion-free source of taxation, as the associated rent is simply transferred from the owners without influencing their incentives (Garnaut, 2010; Mattauch et al., 2013). Furthermore, current tax revenues are insufficient to meet infrastructure investment needs in many developing countries, and possibilities to raise existing taxes or introduce new taxes remain severely restricted by institutional constraints, such as lack of administrative capacity and a large informal sector. For instance, many African countries' tax revenues fall short of infrastructure investment requirements. In Nigeria these costs exceed tax revenue by a factor of 12, in Ethiopia by 20, and in the Democratic Republic of Congo by almost 26 (World Bank, 2014). Hence, resource rent taxation is an attractive option from a theoretical perspective. ${ }^{1}$ In addition, resource taxes are less prone to tax evasion (Markandya et al., 2013). Second, from an ethical point of view, it has been argued that natural resources should belong to the whole society (Pogge, 2007). From this perspective, investing resource rents into public infrastructure, the benefits of which accrue to all citizens, can be regarded as highly equitable. In addition, it might be difficult for individuals to pool their resource dividends in order to realize large-scale infrastructure projects. Resource rent estimates by the World Bank (2014) exceed 3 trillion US\$ for 2010. Even though some

${ }^{1}$ Barma et al. (2012) state that even though taxing resources requires less effort than taxing other economic activities, and thus could provide considerable rents at relative administrative ease, to date many resource-dependent countries neglect revenue administration capacity development, which could increase public revenues. 
of them are already appropriated, ${ }^{2}$ it is not unlikely that the remainder could cover at least some of the gaps in access to infrastructure across the globe.

\section{Literature review and contribution}

This paper contributes to three different strands of literature. First, it follows previous studies estimating infrastructure investment needs. In the literature, the prevalent method uses future GDP projections to extrapolate empirically the observed relationship between investment and GDP (e.g., Estache, 2010; Kohli and Basil, 2011). By contrast, relatively few contributions examine investment needs to achieve specific human development goals in terms of access to infrastructure services, such as either the ones specified in the Millennium Development Goals (MDGs), or universal access. Notable exceptions that constitute the basis for the cost estimates used in this paper include Pachauri et al. (2013) for electricity and Hutton (2012) for water and sanitation.

Secondly, our paper draws on the literature on taxation and management of natural resource rents. Henry George (1879) and Feldstein (1977), as well as Arnott and Stiglitz (1979) examined the conditions under which taxation of fixed factors of production (such as land) has distortive impacts. More recently, Edenhofer et al. (2013) have identified conditions under which resource rent taxation can even raise social welfare by correcting overinvestment in fixed factors of production. Furthermore, the management of resource rents is addressed by a vast literature on the so-called 'natural resource curse' (see van der Ploeg, 2011, for a review), which emphasizes the important role of institutions and targeted investment of resource revenues for natural resource wealth to result in welfare improvements.

Thirdly, our paper is related to the sustainable development literature. Carrying out a thought experiment in which resource rents are entirely invested in public infrastructure, it (at least roughly) exemplifies the Hartwick (1977) rule, which states that use of exhaustible resources can only go hand in hand with sustained economic activity if the proceeds are used to build up a capital stock that substitutes for the foregone 'natural capital' (Hamilton and Clemens, 1999; Arrow et al., 2004). This approach embodies the concept of 'weak sustainability', which assumes that constructed capital can substitute for natural capital (Neumayer, 2010). The issue of using rent taxation to finance public infrastructure is examined in a theoretical framework by Mattauch et al. (2013), who illustrate how taxing fixed factors eliminates the tradeoff between public good provision and the disadvantages of distortionary taxation. Furthermore, insofar as providing access to infrastructure also expands the capability of individuals and their opportunities, the insights from this paper are also interesting for the community employing the so-called 'capability approach' to development first put forward by Sen $(1992,1999)$.

2 See, for example, Land (2008), who finds a range of 0-75 per cent of resource rents to be already appropriated, with most of the resources featuring rent appropriation rates around 20 per cent; see also section 4 . 
Our paper is, to our knowledge, the first to examine the empirical relevance of using the revenues from taxes on resource rents in order to promote human development by means of providing access to basic infrastructure services, such as water, sanitation, electricity, transport and telecommunications. A seminal contribution combining resource rent taxation and alleviation of income poverty is by Segal (2010), who highlights that full redistribution of resource rents could reduce the global number of people living on less than US\$1 a day by up to two-thirds. ${ }^{3}$ An additional contribution is that we provide a newly compiled data set, based on different sources and our own assumptions and calculations, for the comparison of infrastructure gaps and the cost of closing them, which we additionally merge with an extrapolation of resource rents from the World Development Indicators (WDI) (World Bank, 2014).

\section{Methodology and data}

In section 3.1 we describe the data used to estimate the gaps in access to the different types of infrastructure we chose to focus on; section 3.2 introduces the costs to close access gaps. For the computation of the resource rents, we rely on the most comprehensive and up-to-date data set available under the WDI (World Bank, 2014). Section 3.3 outlines the information on resource rents contained in this data set and the major assumptions that have been made for this study, while a full ready-to-use spreadsheet with all inputs and outputs can be found in the supplementary materials available at http://journals.cambridge.org/EDE. This database also contains the infrastructure costs, which are presented in the second subsection and which are based on different data sources, sometimes combined in order to increase coverage and/or precision.

\subsection{Access to infrastructure}

The goal of this study is to determine whether resource rents would be sufficient to cover investments to such an extent that it would enable universal (i.e., 100 per cent) access for the respective countries' populations to five types of infrastructure which are agreed to be essential in the development process: water, sanitation, electricity, roads, and information and communication technology (ICT). The World Bank defines access to improved drinking water sources as the provision of piped water on premises (piped household water connection located inside the user's dwelling, plot or yard), and as other improved drinking water sources (public taps or standpipes, tube wells or boreholes, protected dug wells, protected springs and rainwater collection). In the case of sanitation, access refers to the availability for use of flush/pour flush (to piped sewer systems, septic tanks or pit latrines), ventilated improved pit latrine, pit latrine with slab, and composting toilet facilities. Access to electricity is defined as the percentage

${ }^{3}$ Note that Segal's (2010) approach is related to Pogge's (2007) 'Global resource dividend'. Yet, whereas Pogge (2007) argues for global redistribution of resource rents, Segal (2010) considers the arguably more realistic case of redistribution at national level. 
of households with an electricity connection (Pachauri et al., 2013). For telecommunications, we assume that access is enabled by having a mobile phone and 10 minutes of airtime per day (ITU, 2014). For transportation, we do not determine the population shares having access to roads, due to lack of data, but take the length of unpaved roads as a proxy for the demand for (paved) roads (World Bank, 2014).

For our analysis, we first determine the current share of people with access to those infrastructures. These shares are then assumed to remain constant until 2030, except for electricity access, where future access gaps are implicit in the cost of closing the gaps. We do not assume that people can obtain access through, for example, an exogenous increase in income. ${ }^{4}$ Multiplying these shares by the UN population forecast for 2030 (UN, 2013, medium fertility scenario), we obtain the total number of people who have to be connected until the target year, i.e., people who currently do not have access and the people additionally born into this non-access situation up to 2030 .

Figure 1 (which can be seen in colour in the online appendix available at http:/ / dx.doi.org/10.1017/S1355770X16000139) displays in five panels the access maps for the different infrastructure types. ${ }^{5}$ Note again that in the absence of a coherent data set on populations' access to roads, we resorted to using unpaved roads as a proxy for the demand for paved roads. We thus implicitly assume that if a transportation channel is needed, then it exists already as an unpaved road. Clearly, not all roads might carry the same return, e.g., in terms of connecting people to markets once paved. Nevertheless, this proxy should enable us to make an estimate of the costs of satisfying road demand that will not underestimate the resource rent shares needed to pave the roads for transport.

Figure 1 clearly shows that, globally, access gaps are lowest for water, whereas lack of access is more pronounced for sanitation, electricity and telecommunications. In terms of paving unpaved roads, the 'gaps' appear to be largest in parts of Africa and Latin America, even though the amount of grey countries indicates that data availability prevents us from giving a more comprehensive picture here.

Gaps for all infrastructures are most severe for Africa. For instance, in many African countries more than half of the population lacks access to electricity, sanitation and communication technology. Other 'hotspots' include South Asia, with severe access gaps for sanitation and telecommunications, and some countries in Southeast Asia.

${ }^{4}$ We realize that this is a conservative assumption, as indeed it can be observed that increased GDP is positively correlated with improved access (Pachauri et al., 2013). However, in this study we strictly focus on all investment needed to close the existing gaps for our calculations of the needed resource rent shares. Thus, our estimates can be regarded as an upper bound of resource shares needed with potential downwards as incomes rise.

5 In the supplementary material, we offer a different visualization based on bar graphs, which enables a more precise comparison of the magnitudes of the access gaps. 

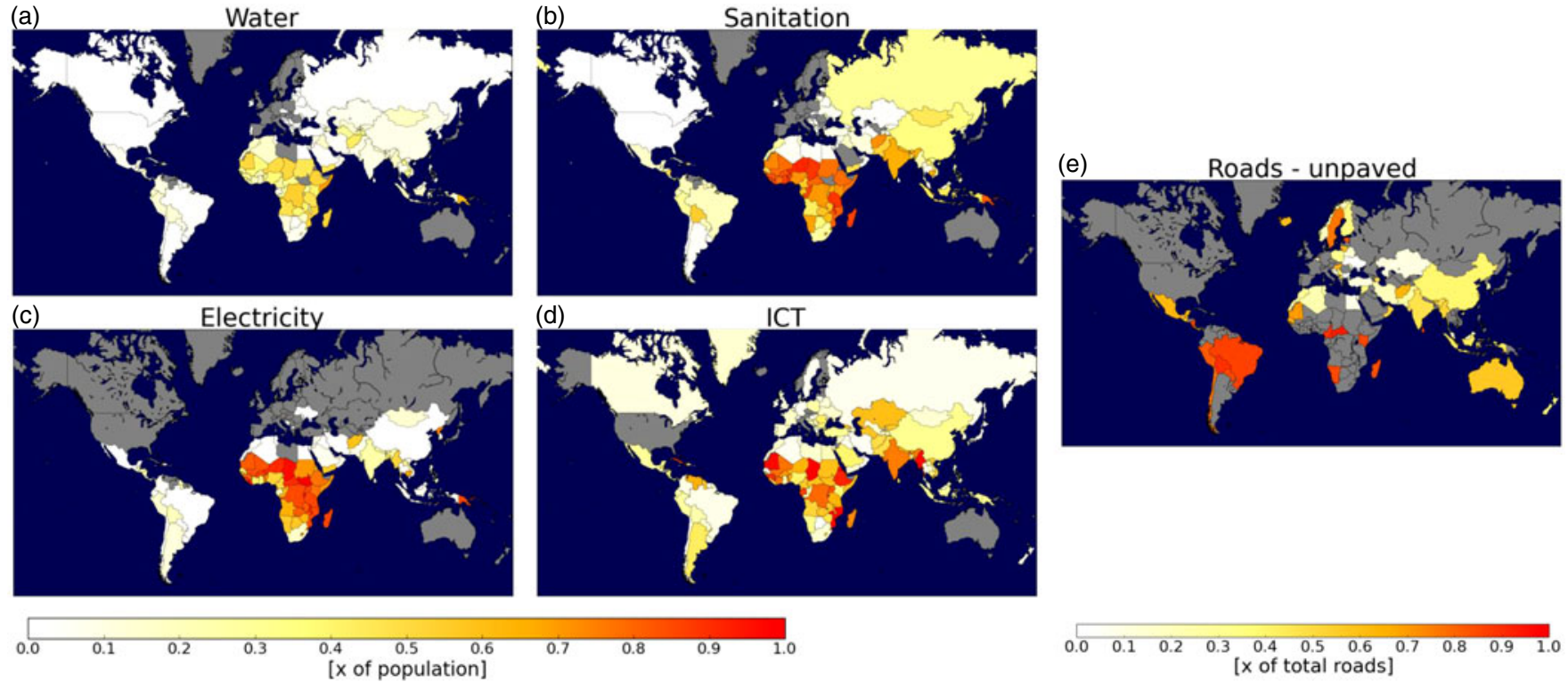

Figure 1. Share of population without access to: (a) water, (b) sanitation, (c) electricity, and (d) telecommunications. Panel (e) shows the share of unpaved roads in total roads. Countries with missing data are shaded in grey; white areas show countries with 100 per cent access 
Table 1. Total costs of closing access gaps in millions of 2010 US\$

\begin{tabular}{|c|c|c|c|c|c|c|}
\hline & Electricity & Water & Sanitation & $I C T$ & Roads & Total \\
\hline $\begin{array}{c}\text { East Asia \& } \\
\text { Pacific }\end{array}$ & 13,914 & 92,908 & 87,480 & 512,576 & $2,332,130$ & $3,039,008$ \\
\hline $\begin{array}{l}\text { Europe \& } \\
\text { Central } \\
\text { Asia }\end{array}$ & 0 & 5,655 & 12,344 & 105,825 & 333,100 & 456,924 \\
\hline $\begin{array}{l}\text { Latin } \\
\text { America \& } \\
\text { Caribbean }\end{array}$ & 13,935 & 29,868 & 41,257 & 130,846 & $2,215,966$ & $2,431,872$ \\
\hline $\begin{array}{l}\text { Middle East } \\
\text { \& North } \\
\text { Africa }\end{array}$ & 4,598 & 17,891 & 13,312 & 49,486 & 135,604 & 220,890 \\
\hline $\begin{array}{l}\text { North } \\
\text { America }\end{array}$ & 0 & 0 & 0 & 3,419 & 0 & 3,419 \\
\hline South Asia & 35,861 & 5,044 & 105,213 & $1,062,650$ & $2,488,990$ & $3,697,759$ \\
\hline $\begin{array}{l}\text { Sub-Saharan } \\
\text { Africa }\end{array}$ & 351,251 & 36,752 & 150,811 & 672,436 & 256,733 & $1,467,983$ \\
\hline Total & 419,559 & 188,118 & 410,418 & $2,537,238$ & $7,762,522$ & $11,317,856$ \\
\hline
\end{tabular}

Source: Authors' own calculations based on UN population forecasts (UN, 2013), WDI database on population shares without access (World Bank, 2014) and costs from different sources: Hutton (2012) for water and sanitation, Pachauri et al. (2013) for electricity, IEA (2013) for roads and ITU (2014) for mobile connections.

\subsection{Infrastructure costs}

Table 1 shows the total cost of providing access to the respective populations without access in the main regions of the world (see also figures 1 and 2). These are the aggregated numbers of the inputs (at country level) that were used to compute the cost ratios for closing the access gaps, which will be presented in the next section. Clearly, the costs of giving access to water appear to be among the lowest, as both the population lacking access is low (see also figure 1) and construction and recurrent costs are much less compared to, e.g., electricity. This leads us to expect that most regions will be able to use their resource rents to finance investment into universal water access.

\subsubsection{Water and sanitation}

For the cost estimate of enabling universal access to clean water and sanitation, we rely on the World Health Organization (WHO) study by Hutton (2012). He provides cost data for water and sanitation in both rural and urban areas, and computes the total costs for two targets: the MDGs and universal access (and the corresponding benefits). In this study, we abstain from making assumptions about benefits, a comprehensive estimation of which would be beyond the scope of our objectives.

For the final results, a number of assumptions are first needed - starting with the problem that Hutton (2012) uses the MDG regions, which are 


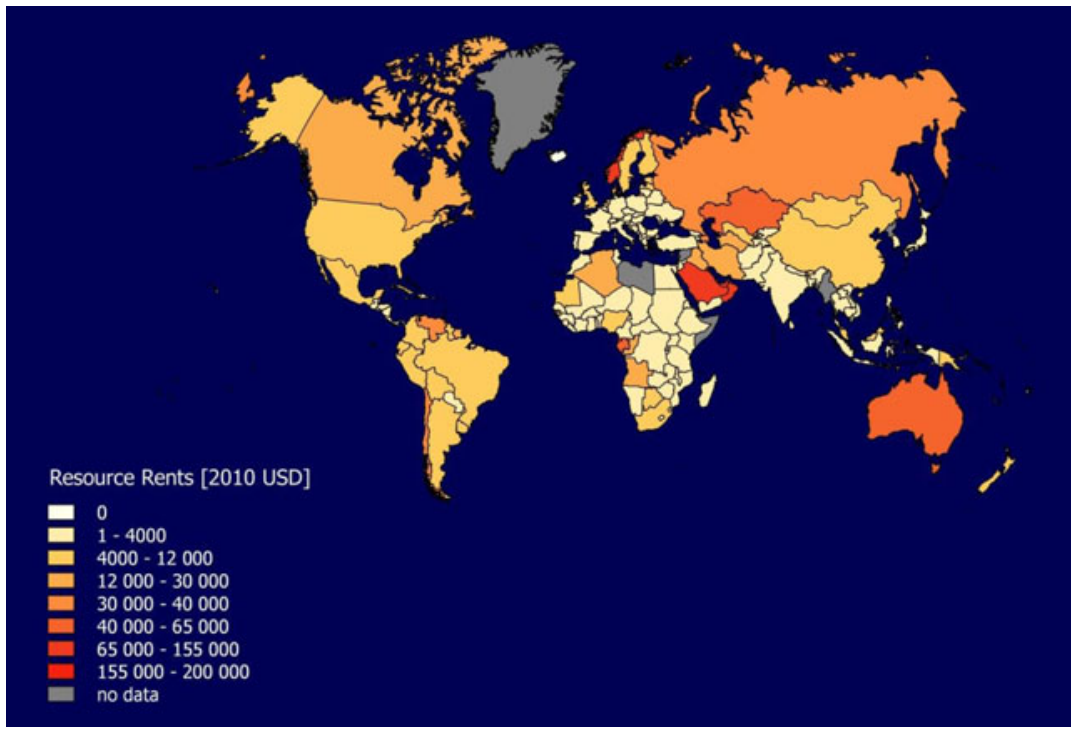

Figure 2. Natural resource rents from forests, oil, gas, coal and minerals, extrapolated until 2030 based on WDI data. Rents were summed over the 15-year period from 2015 to 2030, and are represented per capita based on the estimated population in 2030. White areas have no rents; grey areas have no data available

different from the WDI regions that the resource rent numbers are based on. Therefore, all countries with unclear membership were reassigned to regions based on their location. The country-level data have then been aligned with our population data for 2030 (see also section 3.1), as Hutton (2012) uses different forecasts. These forecasts were not dramatically different and using Hutton's (2012) population data would not have changed our results significantly, yet for reasons of consistency and comparability with the other infrastructure types and precision of the final cost ratios, we transformed the numbers according to the population shares without access derived in section 3.1 .

Where no data were available at country level, the regional average was computed using table $\mathrm{A}^{6}$ in Hutton (2012), and then broken down to US\$ per person per country.

Costs in Hutton (2012) are available for urban and rural areas. We used the sum of both for reasons of comparability with the other infrastructure types. 7

6 Table A (Hutton, 2012: 7) on total financial capital costs to expand coverage to achieve MDG targets and attain universal access for improved drinking water sources and sanitation, from 2011 to 2015.

${ }^{7}$ In the database, the cost share of urban versus rural is given, so the difference could be deducted for each region if needed for more detailed analysis in the future. 
Recurrent costs for water in Hutton (2012) are given as a percentage of total costs for the MDGs. The aggregate numbers are US $\$ 13 \mathrm{bn}$ for sanitation and US\$3bn for water from 2010 until 2015, including operations and maintenance (O\&M) costs. This amounts to 1.86 per cent of total costs for water (i.e., global recurrent cost) and 8.08 per cent for sanitation, both over five years. Extrapolating to 15 years, we assume an average of 7.5 years of recurrent costs, but test for higher costs in section 5. Note that these calculations are for the MDG goals. In order to calculate the total costs for universal access we used the same cost shares and arrive at higher total costs. The same procedure was used for sanitation.

The total cost displayed in table 1 for water and sanitation is the sum of recurrent costs and the sum of urban and rural construction costs, which is later divided by the resource rents to arrive at the results in section 4 .

\subsubsection{Electricity}

For electricity access, a thorough literature review (see also the comparison of studies by Rothman et al., 2014) led us to the conclusion that cost estimates vary vastly, e.g., from US\$1,500 per kW (Fay, 2001, using 1995 US\$) to US\$4,000 per kW (Kohli and Basil, 2011, using 2009 US\$) for Latin America, and around US\$1,900 (Fay and Yepes, 2003, using 1995 US\$) and US\$1,500 (Hughes et al., 2010, using 2009 US\$) globally. This is partially due to the fact that definitions of access vary, where some studies require just a connection while others also integrate the provision of a minimum amount of electricity into final cost numbers. For reasons of consistency and because most of the numbers in the literature were regional or even global averages not taking into account heterogeneity between regions, cost projections from an energy systems model (Pachauri et al., 2013) have been taken as the basis for our calculation.

The advantage of using model estimates for access costs is that we can look much more deeply into the details behind the numbers than is possible with the global averages from the literature, as in this way the technologies specific to, and feasible for, the regions in question have been employed, thus taking into account heterogeneity in energy supply potentials, population density, access to technology and their impact on final costs to consumers. The costs are given in table 2 . Note that they explicitly consider not only the cost of installing the capacity, but also the cost of providing a minimum amount of electricity to each household to cover basic demands, which is contained in the O\&M costs. ${ }^{8}$ Also, in contrast to what has been assumed for the other infrastructure types, the model results take into account the fact that higher incomes can translate to a certain degree to higher access rates as well. We can therefore expect the results to be somewhat less conservative than the ones for water and sanitation.

In the study by Pachauri et al. (2013), cost data are calculated for three regions: South Asia (SAS), Pacific East Asia (PAS) and Sub-Saharan Africa (SSA). Reassigning countries to fit WDI regions, we assumed that the

${ }^{8}$ Note that O\&M costs have been adjusted to 15 years; in Pachauri et al. (2013) the time horizon is 25 years. 
Table 2. Unit costs (in current US\$) for achieving universal electricity access from 2005 until 2030 and costs per connection based on calculations by MESSAGE-ACCESS

\begin{tabular}{lcccr}
\hline & Unit & South Asia & Pacific Asia & Africa \\
\hline Grid investment & US\$bn & 39.7 & 9.6 & 193.2 \\
Generation investment & US\$bn & 2.3 & 1.2 & 2.9 \\
O\&M (incl. fuel) & US\$bn & 2.6 & 1.3 & 5.5 \\
Total cost & US\$bn & $\mathbf{4 4 . 6}$ & $\mathbf{1 2 . 1}$ & $\mathbf{2 0 1 . 6}$ \\
Pop connected & million & 669 & 71 & 605 \\
Grid cost per conn & US\$/capita & 59 & 134 & 319 \\
Total cost per conn & US\$/capita & 67 & 170 & 333 \\
\hline
\end{tabular}

Source: Pachauri et al. (2013) and van Ruijven et al. (2012).

Middle East has costs in the range of PAS, which is in line with numbers given in Crousillat et al. (2010), where universal access by 2030 for the Middle East is estimated to cost 2010 US\$3bn (but starting in 2008 and not in 2015, as in our study). Egypt and Morocco in Northern Africa, Central Asia and the whole of East Asia and the Pacific are assigned the cost of PAS as well. SSA costs have been applied to Latin America and the Caribbean and Algeria, Djibouti, Libya and Tunisia. Europe has virtually no gaps in electricity access. All these assignments have been made mainly by looking at properties such as population density and geographical factors. For countries with missing data, regional averages have been assigned.

The split between the urban and rural population could have been taken from the Sustainable Energy for All (SE4ALL) database, but for total costs, only the rural costs are given in Pachauri et al. (2013), which is why we also use the same numbers for the urban areas, thus neglecting cost-reducing factors such as economies of scale. The costs used can thus be regarded as conservative estimates.

\subsubsection{Roads}

For roads, the WDI contains the total road network at country level in kilometres, and also give the percentage of the network that is paved. We use the length of unpaved roads as a proxy for the demand for paved roads, assuming that these unpaved roads have emerged in response to a need for transportation and connectivity at the location in question. ${ }^{9}$

Concerning the costs of paving these unpaved roads, we use the International Energy Agency's (IEA) report (IEA, 2013, Table 6). Again, the definition of regions is different from the WDI database, so a reassignment similar to the one described in section 3.2.1 has been conducted. For

9 A more in-depth analysis would use geographical methods in order to derive the number of people that would gain access to, for example, markets due to improved road quality, but this is beyond the scope of our study. 
example, the IEA data do not contain Northern Africa as a separate region so the African numbers have been matched to WDI; the same applies to the Caribbean. The assignments of countries to WDI regions can be reviewed in the supplementary material.

Recurrent costs and O\&M costs are separated in the data used, and only O\&M is included (no reconstruction), as we presume that reconstruction is only required after the 15-year horizon that we consider for the build-up of the infrastructure, and we take the reconstruction of existing roads as being part of the 'business-as-usual' scenario instead of being additional. Again, these costs are averaged over a 15-year period. The reason for this assumption is that we want to focus on enabling universal access to infrastructure by 2030, and it is not the objective of this study to include reconstruction beyond that horizon, as otherwise we would also have to include the rebuilding costs of countries which already have full access today. The total costs in table 1 are therefore the sum of the (initial) construction costs and the average O\&M costs until 2030.

\subsubsection{ICT}

For communications, we chose to use the maximum of the share of population with access to fixed lines and mobile connections, respectively. The percentage of the population per country with access to mobile and fixed connections for 2010 (or the latest number that was available for a specific country) has been taken from ITU (2014). ${ }^{10}$ This has been used to compute the amount of people without access in 2030, again based on the medium fertility population forecast by the UN (2013). For countries with missing data, the regional average has been assigned. We assume that all new connections are mobile phones, as this is the more common form currently proliferating in the emerging countries rather than fixed lines and broadband (Aker and Mbiti, 2010).

In order to make a conservative assumption in the absence of any consistent data, the cost for providing access to mobile connections is assumed to be US\$150 in fixed costs per connection. This is in line with the range over different studies surveyed by Rothman et al. (2014). For the cost of usage, we assume 2 cents per minute. For an airtime of 10 minutes over 15 years (again averaging), usage cost thus amounts to US\$547.50. For recurrent cost, 8 per cent of total costs is spread over 7.5 years. Total costs are the sum of fixed costs, usage costs and recurrent costs multiplied by the total population without access in 2030 .

\subsection{Resource rents}

Resource rents, as quoted in the WDI, come from the World Bank (2011) publication, The Changing Wealth of Nations. ${ }^{11}$ Natural resource rents are

10 Where available, data have been taken from 2011, otherwise the assumption is that access does not decrease as we move forward in time.

11 Note that The Changing Wealth of Nations covers the period from 1995 until 2008, but resource rents are updated annually in the Wealth Accounting Database, enabling us to cover a period until 2013. 
calculated from forests, oil, gas, coal and minerals. The latter include bauxite, copper, lead, nickel, phosphate, tin, zinc, gold, silver and iron. In particular, these estimates are computed as the difference between the price of a commodity and the average cost of producing it. This is done by estimating the world price of units of specific commodities and subtracting estimates of average unit costs of extraction or harvesting costs (including a standard return on capital). These unit rents are then multiplied by the physical quantities that countries extract or harvest to determine the rents for each commodity as a share of gross domestic product (GDP). The data used in this study are given in percentages of 2010 GDP. A total of 214 countries are included in the data set; however, 25 countries lack data. These 25 countries can mostly be classified as either small and resource poor, or as having 100 per cent access already.

In order to estimate the amount of resource rents that would, in principle, be available to finance infrastructure investments to close the access gaps described above until 2030, we assume that resource extraction rates and prices remain constant in absolute terms, thus abstaining from any judgement as to the likelihood of peak production or major technological breakthroughs that could decrease costs in the coming decade. We feel that this is a sufficiently conservative assumption to arrive at a robust benchmark for our estimates, and will later test these by introducing some sensitivity analyses (see section 5). Figure 2 (available in colour in the online appendix) displays the resource rents available at constant extraction rates and prices in 2010 US\$ across the globe. On the basis of figures 1 and 2, it appears to be justified to assume that there should be a good chance that resource rents could cover access gaps in Latin America and Asia. Only Africa appears to have a larger share of countries at the lower end of both access and resource rent availability.

As mentioned before, parts of the resource rents are obviously already being appropriated by governments or private stakeholders, and it is questionable how much additional financing could practically be made available during the foreseen time horizon. Coming up with a comprehensive review of current levels of resource rent taxation is beyond the scope of this study and would actually be a stand-alone project in itself. However, for countries that need only a small share of their resource rents to finance their infrastructure goals, it should be feasible to meet them by resource rent taxation, and we conduct a sensitivity analysis halving the amount of rents that can be appropriated and doubling the costs of doing so.

\section{Results}

The extent to which existing gaps in terms of infrastructure access could be covered by resource rents is displayed in figure 3 (available in colour in the online appendix). For water (panel (a)), for almost all countries universal access could be provided at a comparatively low share (about 10 per cent) of annual resource rents. This observation is explained by the fact 

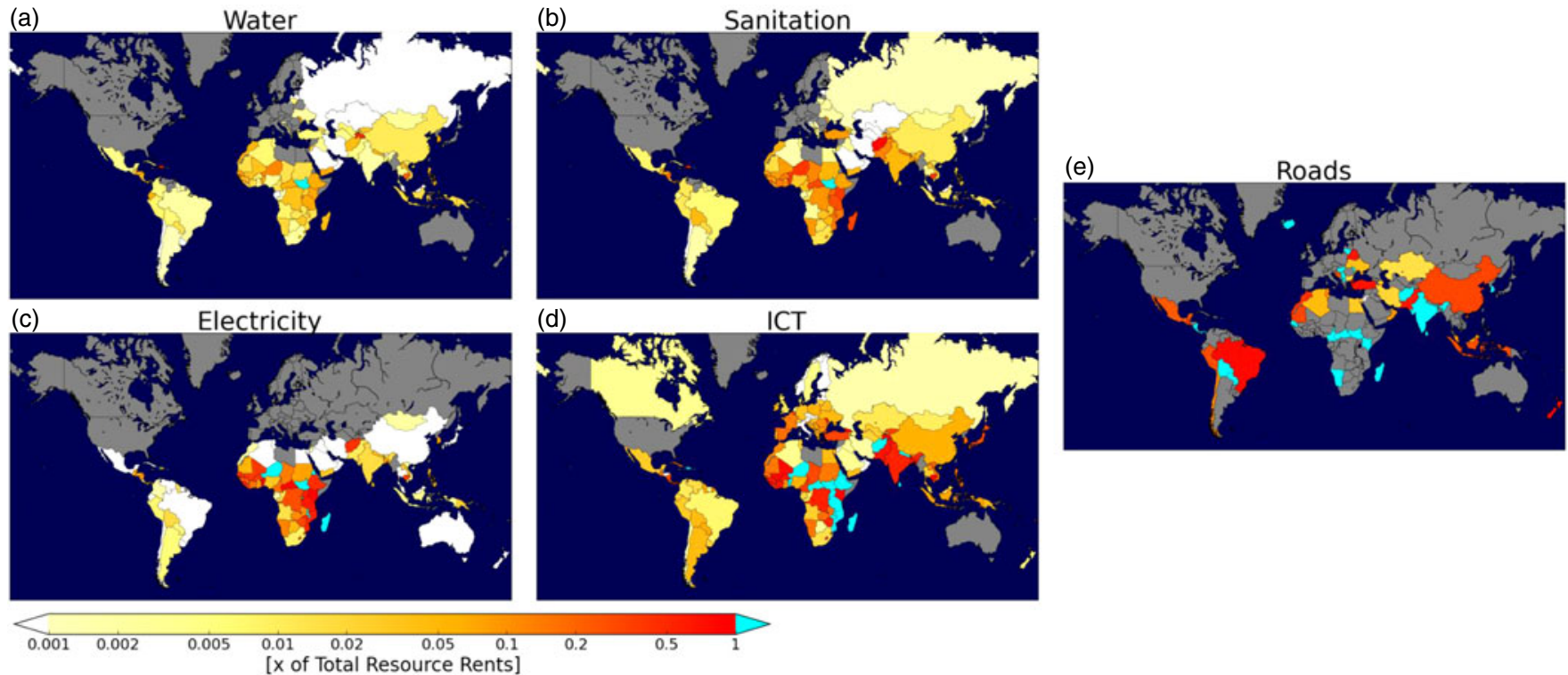

Figure 3. Share of total resource rents required to finance universal access to: (a) water, (b) sanitation, (c) electricity, (d) telecommunications, and (e) transport (scale is logarithmic) 
that: (i) in most regions the access gap for water is lower than for other infrastructures (see figure 1, panel (a)); and (ii) the costs of providing water access are comparatively low (see also section 3.3 ). Note that white-shaded areas are those where the share of resource rents required to achieve universal access is close to zero (i.e., areas that already enjoy almost universal access), whereas grey areas indicate that no data on access gaps or costs are available.

For sanitation (panel (b)), universal access for most of Latin America and Asia could be achieved at 10 per cent or less of annual resource rents. For Africa, on the other hand, requirements are significantly higher, ranging from 10 to 20 per cent for most countries. Nevertheless, resource rents would be sufficient to provide universal access to sanitation for all countries included in our analysis.

For electricity (panel (c)), establishing universal access would require a rather small share of less than 10 per cent of resource rents for most Latin American and Asian countries. For Africa, however, more than half of the resource rents would be required for some countries, and for a small subset of countries it would be infeasible to achieve universal access in the time period under consideration (2015-2030), even if the entire resource rents were invested solely into electricity infrastructure. These include Eritrea, Aruba, Kiribati, Micronesia, St Lucia, St Vincent and the Grenadines, East Timor, Niger and Malawi. The fact that providing electricity for some African countries is found to be rather challenging can be explained by lower access, as well as by the lower population density, which imposes higher costs on building transmission grids. Note that the data do not allow us to look into possibilities of decentralized power solutions for remote areas at this stage. This would be an interesting extension to consider for future research, which would also enable a more detailed analysis of countries without access cost data, such as small island states.

For telecommunications (panel (d)), resource rents would be insufficient to finance universal access in almost one-third of the African countries included in our sample, as well as for some Asian countries. In addition, for several countries in which investment needs do not exceed resource rents, they would nevertheless account for a large portion of the rents. Given that some part of the resource rents would either be needed for investment in water, sanitation, electricity and roads, or might already be appropriated by the state, these observations suggest that the potential for achieving universal access to telecommunications may face a limited potential. On the other hand, however, the cost assumptions of our analysis are rather conservative, and it is conceivable that technological developments could result in cost reductions that would make access to telecommunications significantly less expensive than what our assumptions imply.

Finally, for roads (panel (e)), our results suggest that investment needs to pave all currently unpaved roads in the period 2015-2030 would exceed the resource rents of many countries in our sample, and consume a considerable fraction of resource rents ( $>30$ per cent) for others.

Note that the relatively high resource rent shares for more developed countries such as Japan and South Korea should not come as a surprise. Despite high access rates in these countries, scarce resource endowments 
mean that a relatively large share of rents would be needed to close remaining access gaps.

In summary, our results indicate that resource rent taxation could be likely to provide the means to finance access to the infrastructures directly necessary for subsistence, i.e., to water, electricity and sanitation. Yet, for many countries it would not be sufficient to cover more advanced needs, including requirements for telecommunications and paved roads.

In the next section, we will assess the robustness of our results by testing for the impact of higher and lower costs of access provision and resource rents.

\section{Sensitivity analysis}

Resource rents could change over time due to changes in demand, changes in the quality of the commodity, or special trade agreements, for example. Also, the estimates of unit costs of extraction could differ as they depend on the available technology. We therefore test for the case where resource rents are 50 per cent lower than in the baseline results presented in section 5 . This is not unreasonable, looking at, for example, recent falls in the price of oil, even if this might be just a short- or medium-term phenomenon. In addition, it is a good way of testing the robustness of results in the face of the fact that parts of resource rents are already appropriated (see section 6 for a discussion). Likewise, technological breakthroughs and price hikes could lead to higher resource rents. Therefore, we will also test the case where resource rents are 50 per cent higher. Note that we are not putting forward any claims for the realism of these scenarios here. The main purpose is to test our results along the full spectrum of outcomes, setting two extreme cases between which most of the deviations occurring in reality should be located.

Similarly, we match a 50 per cent higher access cost scenario to the case of higher resource rents, and a 50 per cent more expensive scenario to the case with lower resource rents. In this way, we arrive at the range of sensitivities presented in figure 4 . The deviations in costs could originate from changes in labour and material costs, but also from deviations in discount rates, etc. They will probably not be as high as 50 per cent in reality, but by using such an extreme range we can be confident that we cover all possibilities over which we want our results to be robust.

In figure 4, lower and upper ends of whiskers represent the extreme cases described above. ${ }^{12}$ Evidently, water access is the most easily covered gap. Even in the least favourable scenario, the share of resource rents required to close those gaps, is considerably below 4 per cent. The same applies to East Asia and the Pacific, Europe and Central Asia, Latin America and the Caribbean, and the Middle East and North Africa for both sanitation and electricity access. For sanitation, the share can go up to as high as 17 and 12 per cent for South Asia and Sub-Saharan Africa, respectively. In the case of electricity, it is the other way round, with the lower share for South

12 For regional averages, only countries for which both costs and rents were available have been considered in the sensitivity analysis. 


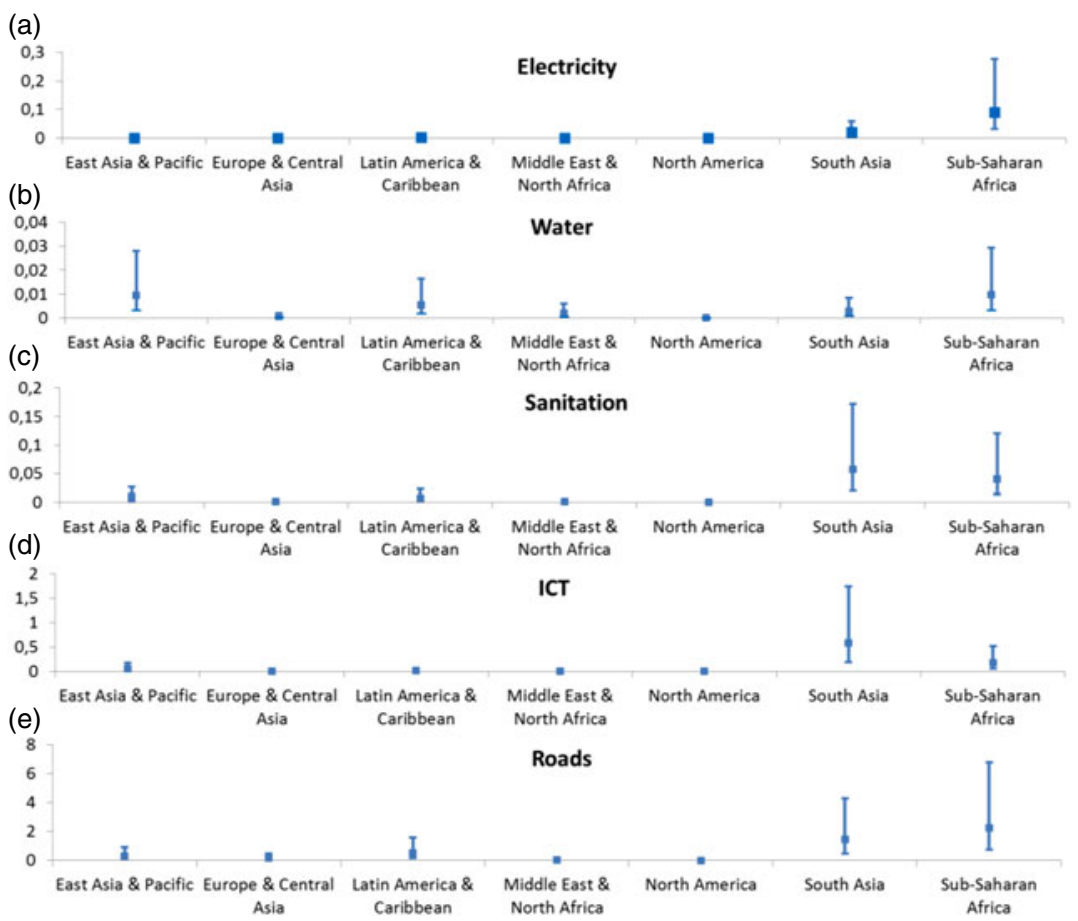

Figure 4. Sensitivity analysis results show share of resource rents required to finance universal access to infrastructure: (a) electricity, (b) water, (c) sanitation, (d) telecommunications, and (e) transport

Notes: In the case of Transport, the indicator is not in terms of population shares having access to roads, but in terms of $\mathrm{km}$ of unpaved roads as a proxy for paved road demand. For further description of data and sources, see section 2. Upper end of whiskers show the least favourable case with 50 per cent more expensive infrastructure and 50 per cent less rents, and vice versa for the lower end of the whiskers. Please note different scales.

Asia just above 5 per cent, but Sub-Saharan Africa close to a quarter of its total resource rents. Given that the other gaps also need to be closed, Sub-Saharan Africa would struggle to achieve all the goals simultaneously if costs are considerably higher and resource rents lower. It is important to bear in mind, however, that this is an extreme scenario and that the actual number is much more likely to centre somewhere around 8 per cent. The most variation can finally be observed in panels (d) and (e) in figure 4, where we display the whisker plots for the ICT and road sensitivity analyses. For mobile connections, Latin America and the Caribbean falls just short of the 2 per cent threshold for the worst case scenario, and East Asia and the Pacific is in the least favourable scenario, required to spend about 18 per cent of its resource rents to enable universal access to communication (via mobile connections). Sub-Saharan Africa would need to spend more than half of their resource rents on ICT for universal access. In the case of South Asia, the share actually exceeds 100 per cent, i.e., this region will not be able to close the gap through the use of its resource rents alone. For roads, even our central estimate exceeds 100 per cent of resource rents 
for South Asia and Sub-Saharan Africa. Furthermore, the worst case estimate for Latin America would also exceed the available resource rents, and for East Asia and the Pacific the required share is more than 90 per cent.

\section{Resource rent taxation in practice}

The previous sections have demonstrated that resource rents could, at least in theory, provide the financial means to cover infrastructure investment needs for many countries. As highlighted by the literature on the 'natural resource curse' (Sachs and Warner, 1995; van der Ploeg, 2011), resource-dependent countries are frequently affected by problems related to institutional quality. As a consequence, collecting taxes on resource rents and ensuring that they are productively invested requires well-functioning governance mechanisms (Sala-i-Martin and Subramanian, 2003). For example, Caselli and Michaels (2013) examine the effects of resource windfalls on government behaviour in the Brazilian oil sector. They find that social transfers, public good provision, infrastructure and household income increase less than anticipated on the basis of the higher reported spending by oil-rich municipalities.

Yet recent literature has also shown that there are channels through which natural resources may have positive effects for development (Lederman and Maloney, 2008; Wick and Bulte, 2009). That is, natural resource wealth has the potential to adversely affect development outcomes. However, resources are not destiny, but can be used productively by good policy design.

Another aspect that needs to be considered is the political economy of resource rent taxation. Arguably, any attempt to appropriate resource rents would be met by fierce opposition from resource owners. Yet one could argue that public pressure from a broad spectrum of the population who would gain from increased infrastructure access may be sufficient to more than compensate for the influence of powerful special interest groups. In view of the negative empirical association between mineral wealth and democratization (Ross, 2001), ensuring accountability of how resource rents are used is central in order to ensure buy-in of societal coalitions favouring resource rent taxes. Previous experience suggests that the earmarking of revenues, e.g., for infrastructure, can increase government accountability (Dhillon and Perroni, 2001) and the political feasibility of proposed policies (Sclen and Kallbekken, 2011). Hence, dedicating resource rents to infrastructure investments could provide a mechanism that commits policy makers to using these rents in a predetermined way, and thus reduce opportunities for embezzlement.

\section{Conclusions and discussion}

Access to basic infrastructures such as water, sanitation, electricity, telecommunications and transport is an essential feature of human wellbeing. For this reason, access considerations play an important role in existing development policies. In this paper we have argued that, in order to finance infrastructure investment, resource rent taxation is not only an economically efficient source of public finance, but can also be defended 
from a normative point of view. We have contributed to the literature by assembling a consistent database on resource rents, access gaps, and the costs of closing them, to enable this assessment and further analysis in the future, which could focus on different aspects of this work.

The strategy of using resource rents to finance infrastructure investments seems unlikely to work for resource-poor countries with low natural resource endowments (many of which were excluded from our data set due to a lack of available data), e.g., small island states. To achieve universal access to infrastructure services in these countries, alternative funding sources need to be envisaged. Besides existing traditional channels of development cooperation, one opportunity to levy additional public revenue consists of imposing a price on greenhouse gas emissions by means of a tax, or an emissions trading scheme, as analysed by Jakob et al. (2016).

In addition, the extent to which new public revenue can be generated by resource rent taxation crucially depends on the share of resource rents that are currently already appropriated by states, either by means of direct taxation, royalties or public ownership. To our knowledge, no consistent data on the appropriation of resource rents are available. Land (2008) provides an overview of resource rent capture in selected countries (see Land, 2008, Table 1), highlighting the large range of 0-75 per cent of rents being appropriated, with most estimates around 20 per cent. For the case of hard coal, the IEA (2014: 57) points out that in non-OECD countries about two-thirds of reserves (and hence a similar amount of associated rents) are publicly owned. Analysing capture of oil rents for Australia, Brazil, Canada, Norway, the USA and the UK, Mintz and Chen (2012) find numbers ranging from negative (i.e., subsidization) to more than half (see Mintz and Chen, 2012, Table 2). Even though these considerations suggest that the availability of resource rents to finance infrastructure access may be limited in some cases, it also indicates that there is a significant potential, especially for countries and infrastructures for which universal access can be achieved at the cost of only a few per cent of annual resource rents (see figure 5, available in colour in the online appendix).

More support for this optimistic conclusion comes from the fact that our analysis only provides an estimate of the orders of magnitude involved rather than employing a fully fledged model that takes into account feedback effects. Surely the installation of the infrastructure achieving universal access will have impacts on economic development that will feed back into rents, e.g., by increasing demand for natural resources. In this way, infrastructure could even become self-financing to a certain extent (Gaffney, 2009), which is a feature that the framework of our study does not consider.

Finally, in this study the focus has been on physical infrastructure types, whereas 'soft' or social infrastructure is often put forward as being at least as important for a country's development process (Rothman et al., 2014). Those types of infrastructures, being defined as the social foundations of society and taking forms such as a legal system or a government (Rothman et al., 2014), can be fostered by closing 'access gaps' in, for example, education and improving health services.

Summarizing the results, our study indicates that appropriation of resource rents could indeed make a large contribution towards closing 

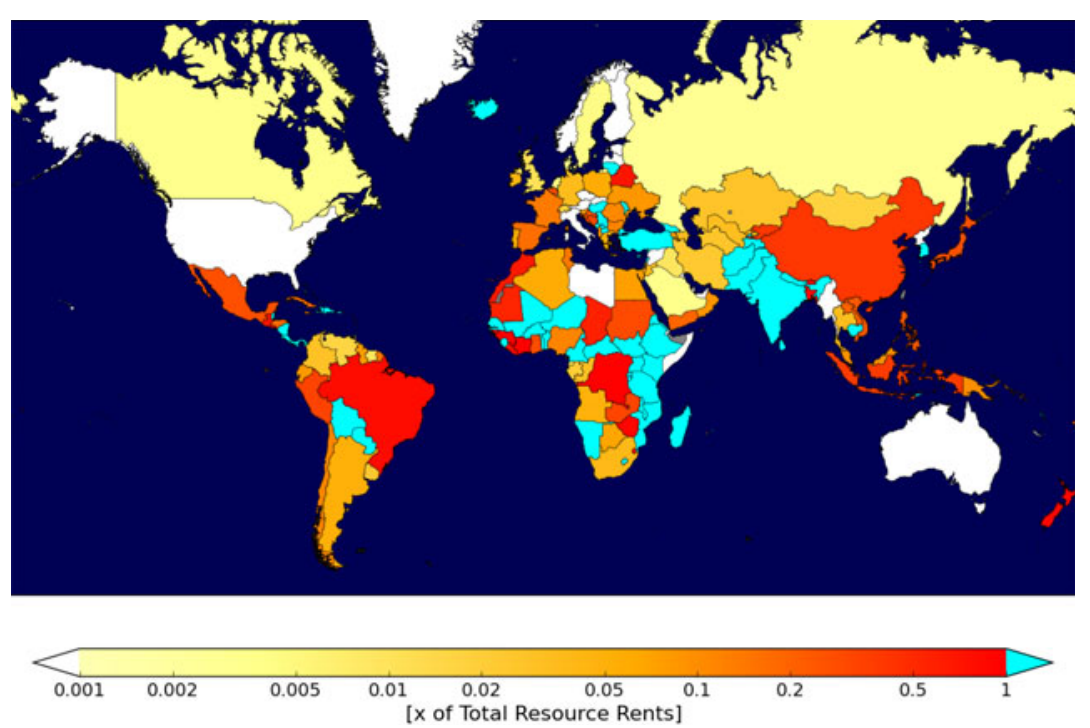

Figure 5. Total share of resource rents needed to simultaneously achieve universal access to electricity, water, sanitation and communications and to pave all unpaved roads (scale is logarithmic)

existing access gaps in most parts of the world. Most importantly, with the view of achieving universal access in the period 2015-2030, the annual resource rents exceed the investment requirements for water, sanitation and electricity in practically all the countries under study. Even though resource rents are insufficient to ensure access to telecommunications and paved roads in all the countries, and even if the full rents are not available for appropriation (as some parts of them are already captured), resource rent taxation can significantly alleviate the financial burden on public budgets.

\section{Supplementary material and methods}

To view supplementary material for this article, please wait http://dx.doi. org/10.1017/S1355770X16000139.

\section{References}

Aker, J.C. and I.M. Mbiti (2010), 'Mobile phones and economic development in Africa', Working Paper No. 211, Center for Global Development, [Available at] http://www.cgdev.org/content/publications/detail/1424175/.

Arnott, R.J. and J.E. Stiglitz (1979), 'Aggregate land rents, expenditure on public goods, and optimal city size', Quarterly Journal of Economics 93(4): 471-500.

Arrow, K., P. Dasgupta, L. Goulder, G., et al. (2004), 'Are we consuming too much?', Journal of Economic Perspectives 18(3): 147-172.

Barma, N.H., K. Kaiser, T.M. Le, and L. Vinuela (2012), Rents to Riches? The Political Economy of Natural Resource-Led Development, Washington, DC: World Bank, [Available at] http://ideas.repec.org/b/wbk/wbpubs/2381.html. 
Calderón, C.A. and L. Servén (2014), 'The effects of infrastructure development on growth and income distribution', Annals of Economics and Finance 15(2): 521-534.

Caselli, F. and G. Michaels (2013), 'Do oil windfalls improve living standards? Evidence from Brazil', American Economic Journal: Applied Economics 5(1): 208-238.

Crousillat, E., R. Hamilton, and P. Antmann (2010), 'Addressing the electricity gap', Background Paper for the World Bank Group Energy Sector Strategy, [Available at] http://siteresources.worldbank.org/EXTESC/Resources/Addressingthe_Electricity_Access_Gap.pdf.

Dhillon, A. and C. Perroni (2001), 'Tax earmarking and grass-roots accountability', Economics Letters 72(1): 99-106.

Drèze, J. and A. Sen (2013), An Uncertain Glory: India and Its Contradictions, Princeton, NJ: Princeton University Press.

Edenhofer, O., L. Mattauch, and J. Siegmeier (2013), 'Hypergeorgism: when is rent taxation as a remedy for insufficient capital accumulation socially optimal?', CESifo Working Paper Series No. 4144, CESifo Group, Munich, [Available at] http://ideas.repec.org/p/ces/ceswps/_4144.html.

Estache, A. (2010), 'Infrastructure finance in developing countries: an overview', EIB Papers 15(2): 60-88, [Available at] http://www.eib.org/attachments/efs/ eibpapers/eibpapers_2010_v15_n02_en.pdf\#page=62.

Estache, A. and M. Fay (2007), 'Current debates on infrastructure policy', Policy Research Working Paper No. 4410, Washington, DC: World Bank, [Available at] http:/ / citeseerx.ist.psu.edu/viewdoc/download?doi=10.1.1.621.9592\&rep=rep1 \&type $=$ pdf.

Fay, M. (2001), 'Financing the future: infrastructure needs in Latin America, 200005', Policy Research Working Paper No. 2545, Washington, DC: World Bank, [Available at] http://ideas.repec.org/p/wbk/wbrwps/2545.html.

Fay, M. and T. Yepes (2003), 'Investing in infrastructure: what is needed from 2000 to 2010?', Policy Research Working Paper No. 3102, Washington, DC: World Bank, [Available at] http://ideas.repec.org/p/wbk/wbrwps/3102.html.

Feldstein, M.S. (1977), 'The surprising incidence of a tax on pure rent: a new answer to an old question', Journal of Political Economy 85(2): 349-360.

Gaffney, M. (2009), 'The hidden taxable capacity of land: enough and to spare', International Journal of Social Economics 36(4): 328-411.

Garnaut, R. (2010), 'Principles and practice of resource rent taxation', Australian Economic Review 43(4): 347-356.

George, H. (1879), Progress and Poverty, Raleigh, NC: Lulu Press.

Hamilton, K. and M. Clemens (1999), 'Genuine savings rates in developing countries', World Bank Economic Review 13(2): 333-356.

Hartwick, J.M. (1977), 'Intergenerational equity and the investing of rents from exhaustible resources', American Economic Review 67(5): 972-974.

Hughes, G., P. Chinowsky, and K. Strzepek (2010), 'The costs of adaptation to climate change for water infrastructure in OECD countries', Utilities Policy 18(3): 142-153.

Hutton, G. (2012), 'Global costs and benefits of drinking-water supply and sanitation interventions to reach the MDG target and universal coverage', WHO/HSE/WSH/12.01, Geneva: World Health Organization, [Available at] http:/ / www.who.int/water_sanitation_health/publications/2012/globalcosts. pdf.

IEA (2013), ‘Global land transport infrastructure requirements: estimating road and railway infrastructure capacity and costs to 2050 ', Information Paper, Paris: International Energy Agency, [Available at] http://www.iea.org/publications/freepu blications/publication/transportinfrastructureinsights_final_web.pdf. 
IEA (2014), ‘World Energy Investment Outlook', Special Report, Paris: International Energy Agency.

ITU (2014), World Telecommunication/ICT Indicators Database (18th edn), Geneva: ITU, [Available at] http://www.itu.int/en/ITU-D/Statistics/Pages/publications/ wtid.aspx.

Jakob, M., C. Chen, S. Fuss, A. Marxen, N.D. Rao, and O. Edenhofer (2016), 'Carbon pricing revenues could close infrastructure access gaps', World Development 84: 254-265.

Kohli, H.A. and P. Basil (2011), 'Requirements for infrastructure investment in Latin America under alternate growth scenarios: 2011-2040', Global Journal of Emerging Market Economies 3(1): 59-110.

Land, B.C (2008), 'Resource rent taxation - theory and experience', Prepared for the IMF Conference on Taxing Natural Resources: New Challenges, New Perspectives, 25-27 September, [Available at] http:/ /www.imf.org/external/np/seminars/eng/2008/ taxnatural/pdf/land.pdf.

Lederman, D. and W.F. Maloney (2008), 'In search of the missing resource curse', Policy Research Working Paper No. 4766, Washington, DC: World Bank, [Available at] http:/ /ideas.repec.org/p/wbk/wbrwps/4766.html.

Markandya, A., M. González-Eguino, and M. Escapa (2013), 'From shadow to green: linking environmental fiscal reforms and the informal economy', Energy Economics 40(Suppl. 1): S108-S118.

Mattauch, L., J. Siegmeier, O. Edenhofer, and F. Creutzig (2013), 'Financing public capital through land rent taxation: a macroeconomic Henry George theorem', Working Paper No. 4280, Munich: CESifo.

Mintz, J. and D. Chen (2012), 'Capturing economic rents from resources through royalties and taxes', University of Calgary SPP Research Paper 30(5).

Neumayer, E. (2010), Weak Versus Strong Sustainability (3rd edn), Cheltenham: Edward Elgar.

Pachauri, S., B.J. van Ruijven, Y. Nagai, K. Riahi, D.P. van Vuuren, A. BrewHammond, and N. Nakicenovic (2013), 'Pathways to achieve universal household access to modern energy by 2030', Environmental Research Letters 8(2): 024015.

Pogge, T.W. (2007), World Poverty and Human Rights (2nd edn), Oxford: John Wiley \& Sons.

Ross, M. (2001), 'Does oil hinder democracy?', World Politics 53(3): 325-361.

Rothman, D.S., M.T. Irfan, B.B. Hughes, E. Margolese-Malin, and J.D. Moyer (2014), Building Global Infrastructure, Patterns of Potential Human Progress series, Boulder, CO: Paradigm Publishers.

Sachs, J.D. and A.M. Warner (1995), 'Natural resource abundance and economic growth', NBER Working Paper No. 5398, Cambridge, MA: National Bureau of Economic Research, [Available at] https://ideas.repec.org/p/nbr/nberwo/5398. html.

Sala-i-Martin, X. and A. Subramanian (2003), 'Addressing the natural resource curse: an illustration from Nigeria', NBER Working Paper No. 9804, Cambridge, MA: National Bureau of Economic Research, [Available at] http://ideas.repec. org/p/nbr/nberwo/9804.html.

Sclen, H. and S. Kallbekken (2011), 'A choice experiment on fuel taxation and earmarking in Norway', Ecological Economics 70(11): 2181-2190.

Segal, P. (2010), 'Resource rents, redistribution, and halving global poverty: the resource dividend', World Development 39(4): 475-489.

Sen, A. (1992), Inequality Re-Examined, Oxford: Clarendon Press.

Sen, A. (1999), Development as Freedom, Oxford: Oxford University Press.

UN (2013), 'World population prospects: the 2012 revision', New York: United Nations, [Available at] http:/ /esa.un.org/wpp/. 
van der Ploeg, F. (2011), 'Natural resources: curse or blessing?', Journal of Economic Literature 49(2): 366-420.

van Ruijven, B.J., J. Schers, and D.P. van Vuuren (2012), 'Model-based scenarios for rural electrification in developing countries', Energy 38(1): 386-397.

Wick, K. and E. Bulte (2009), 'The curse of natural resources', Annual Review of Resource Economics 1(1): 139-156.

World Bank (2011), The Changing Wealth of Nations, Washington, DC: World Bank, [Available at] http:/ / siteresources.worldbank.org/ENVIRONMENT/Resources / ChangingWealthNations.pdf.

World Bank (2014), World Development Indicators, Washington, DC: World Bank, [Available at] http://databank.worldbank.org/data/views/variableselection/ selectvariables.aspx?source=world-development-indicators. 